\title{
Tegnologie en sinvolle bestaan in Afrika ${ }^{1}$
}

\author{
Attie van Niekerk \\ Departement Godsdiens- en Sendingwetenskap \\ Universiteit van Pretoria
}

\begin{abstract}
Technology and meaningful existence in Africa

In dealing with the human capability to improve reality, there are both pessimistic and optimistic views. Pessimistic views include the ancient Greek tragedies and the second law of thermodynamics according to which the level of chaos, or enthropy, increases in any closed system. Optimistic views include the modern Western belief in progress through human control over nature, through technology. Optimistic views are found in some postmodern chaos theories. The Nedcor- Old Mutual Scenarios of 1992 presented an optimistic view. The scenarios advocated massive investment in socio-economic programmes in South Africa dealing with housing, electrification, education, job creation and containing HIVIAIDS. The actual results however are disappointing. A more realistic view is found in the Bible: The power of chaos, sin and death is never underestimated and thus one cannot be optimistic. But the Kingdom of God, which began with Jesus Christ, prevents us from becoming pessimistic, and gives us hope. Such an approach would lead to more meaningful results than either an optimistic or a pessimistic approach would achieve.
\end{abstract}

\section{INLEIDING}

ESKOM se visie vir Afrika, soos in 2002 in 'n advertensie weergegee, is krag en ekonomiese groei: "Met behulp van elektrisiteit kan die Sahara-woestyn bewerkbare landbougrond word." Dit is 'n groot en inspirerende visie. Dit is 'n voorbeeld van die vergesigte wat die tegnologie vir ons kan oopmaak. Is dit egter 'n sinvolle visie? ESKOM se visie word hier gebruik as 'n gevallestudie om 'n antwoord te soek op die vraag na 'n sinvolle bestaan vir 'n wetenskaplike, wat ook 'n Christen is, in Afrika vandag.

\footnotetext{
1. Verwerking van 'n lesing gehou by ' $n$ konferensie: "Tegnologie, waardes en die Universiteit van die 21ste eeu", Potchefstroomse Universiteit vir Christelike Hoër Onderwys, 4-5 September 2001.
} 


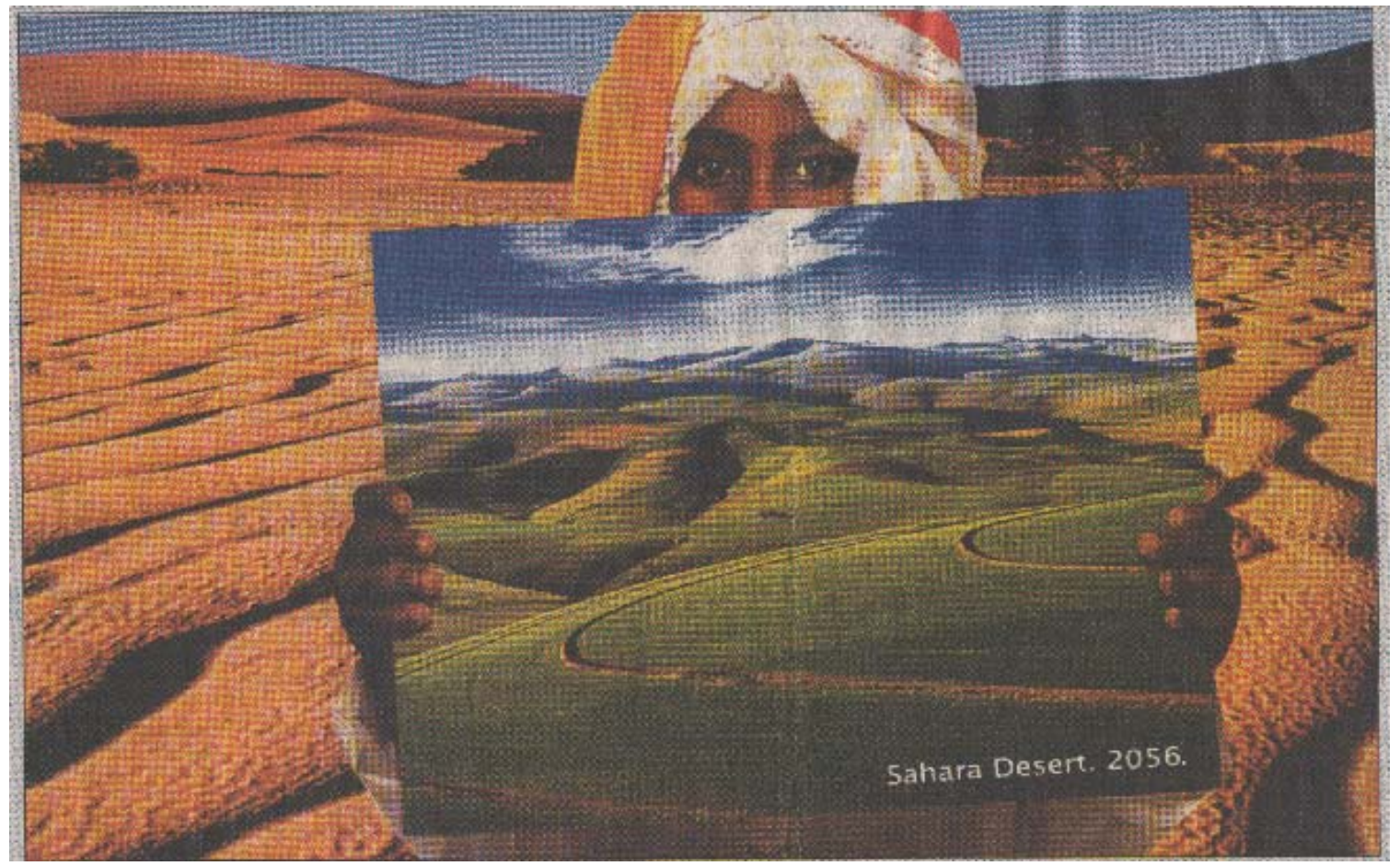

Die ESKOM-visie vir Afrika word uitgebeeld deur 'n virtuele voorstelling van 'n meisie klaarblyklik Arabies - met tradisionele drag aan, wat 'n foto van vrugbare landerye vashou, teen die agtergrond van die dorre en dooie Sahara-woestyn. Die landerye wys hoe die Saharawoestyn in die jaar 2056 kan lyk, deur energie, in die vorm van elektrisiteit, te gebruik.

\section{2. "SINVOL" AS VOORWAARDE VIR BESTAAN}

Die woord "sinvol" dui op 'n belangrike voorwaarde vir 'n gelukkige lewe en selfs vir blote voortbestaan. Die Joodse sielkundige Victor Frankl (1980:11) het as gevangene in die Duitse strafkampe tydens die Tweede Wêreldoorlog opgemerk dat mense wat iets het om voor te leef, iets wat sin en betekenis aan hulle lewe gee, beter oorleef het as mense wat bloot sterk en gesond was. Sin en betekenis dra meer by tot die wel-wees van 'n individu of 'n groep as wat groot rykdom, blakende gesondheid, beroemdheid, sukses of gunstige politieke en ekonomiese omstandighede kan bydra. Die motivering om te volhard kom uit die besef dat jy onvervangbaar en onuitruilbaar is en 'n verantwoordelikheid het vir 'n wagtende taak of wagtende mense. Die vraag is: vir watter wagtende taak is tegnologie in Afrika vandag onvervangbaar? As daar só 'n taak is, maak dit die bestaan van mense wat daardie taak kan help vervul, sinvol. Bied ESKOM se visie 'n voorbeeld van 'n sinvolle taak vir tegnologie? 
Om vir ons sinvol te wees, moet 'n visie ooreenstem met dit wat vir ons waarde het, dit waaraan ons glo. En dit moet haalbaar of bereikbaar wees. Die vraag of ESKOM se visie vir Afrika sinvol is, kan daarom aan twee voorwaardes getoets word: Stem die visie ooreen met dit waaraan ons glo? En is dit prakties haalbaar? Om hierdie twee vrae te kan beantwoord, sal ESKOM se visie nou van verskillende kante af bekyk word.

\section{PESSIMISTIESE SIENINGS: DIE TWEEDE WET VAN DIE TERMODINAMIKA EN DIE GRIEKSE TRAGEDIES}

Die tweede wet van die termodinamika het oor die afgelope paar eeue ontwikkel en steeds verander, maar word tans nog algemeen gebruik in die sin dat die graad van wanorde, of entropie, in 'n geslote stelsel altyd toeneem. Die wanorde kan slegs gestuit of in orde omskep word, deur orde van buite toe te voeg. Om orde by te voeg, vereis werk of energie (Jammer 1973:112-120).

Ons ken die verskynsel uit eie ervaring. Ons sien wat gebeur as 'n huis en 'n tuin onversorg gelaat word. Bossies neem die grasperk en blombeddings oor. Die verf dop af. Muise en goggas teel aan. Mettertyd verval die huis tot 'n murasie. Waar 'n sekere orde was, kom wanorde. Ons kan ook sê dat 'n ander, meer natuurlike, maar vir die mens onbewoonbare, orde ontstaan. Selfs hierdie natuurlike orde het energie van buite nodig. Sonder die sonenergie wat daagliks op die aarde skyn, word ons pragtige planeet gou weer woes, donker en leeg.

Dit is moontlik om orde in 'n gegewe stelsel te vermeerder, maar daar is een komplikasie. Ten einde orde tot een stelsel toe te voeg, word daar dikwels groter wanorde in ' $n$ tweede stelsel of stelsels geskep. Pogings om orde in een stelsel te vermeerder, kan gevolglik die totale wanorde in twee of meer stelsels gesamentlik laat vermeerder. Die son laat die aarde leef, maar uiteindelik brand die son self uit. Volgens hierdie teorie moet chaos in die heelal as geheel steeds toeneem. En op die kleiner skaal van ons direk ervaarbare werklikheid is dit dieselfde: ons pogings om dinge beter te maak - onder andere deur die tegnologie te gebruik - loop herhaaldelik daarop uit dat die totale wanorde in die groter geheel vermeerder en nie verminder nie. Die tweede wet van die termodinamika lei tot 'n pessimistiese beskouing.

Voorbeelde is daar ongelukkig baie. Mediese tegnologie verlig mense se lyding, maar dra by tot bevolkingsgroei wat ellende meebring. Die skepping ly swaar onder besoedeling weens fabrieke en motors wat mense se lewe vergemaklik. Die vrystelling van kweekhuisgasse lei tot vrese dat die wêreld al hoe warmer word. 
Om 'n woonhuis daar te stel en ordelik te laat funksioneer word skade êrens aangerig: lug, water, grond, plante en diere, selfs mense, betaal 'n prys. Byvoorbeeld: ' $n$ Gesin wat 1000 eenhede elektrisiteit per maand gebruik, het die volgende impak op die omgewing: $490 \mathrm{~kg}$ steenkool is verbruik, $850 \mathrm{~kg}$ koolsuurgas ('n kweekhuisgas) is vrygestel, $140 \mathrm{~kg}$ as is geproduseer en 1210 liter water is verbruik (sien ESKOM se webblad, environmental report). Deur orde (tydelik) in die huis te verhoog, is langermyn skade elders gedoen.

Hierdie pessimistiese siening stem grootliks ooreen met die boodskap van die antieke Griekse tragedies. Die Griekse woord mataios dui op die nietigwording, die sinloosheid, die neiging tot chaos wat mense in die lewe ervaar. Die vraag of die mens hierdie neiging kan oorkom, is reeds in die antieke Griekse wêreld gevra. Sommige Griekse filosowe het geglo dat die mens deur sy wysheid, sy verstand, die mataios kan oorkom. Die Griekse tragedies het egter gesê dat die tragedie van ons menslike bestaan is dat ons beste pogings om die nietigwording te oorkom, juis daardie nietigwording aanhelp en veroorsaak. Dit is die tragiese siening van die werklikheid.

Die idee is later selfs op die gode toegepas. Selfs die gode, die hoofgod Zeus ingesluit, is aan die mataios onderworpe. Dit beteken dat daar geen uitkoms is nie. Die Griekse filosofie kon geen antwoord op hierdie pessimistiese siening vind nie en het, in 'n soort gelatenheid, die vraag daar gelaat en aangegaan met die lewe (Bauernfeind 1942: 525-529).

\section{OPTIMISTIESE SIENINGS}

Naas die pessimistiese sienings is daar optimistiese sienings van die werklikheid, wat 'n teenpool bied vir die pessimistiese sienings. Die modernisme wat die Westerse denke sedert die Aufklärung en Renaissance oorheers het, is optimisties oor vooruitgang in die geskiedenis, juis deur tegnologie.

In die Europese Renaissance het die gedagte sterk na vore gekom dat die mens die Verlore Paradys self sal herwin deur oor die natuur te heers en so 'n beter wêreld te skep. Dit is die verligtingsdenke, wat soms as 'n selfstandige geloof teenoor die Christelike gesien word (Goudzwaard 1978:39, 46, 51). Die mens met sy tegnologie, en nie God nie, word die verlosser.

Daar is, aan die ander kant, teoloë wat redeneer dat God die tegnologie kan gebruik om groter orde in sy skepping te bring, want tegnologie is ' $n$ kragtige instrument om orde in 'n bepaalde stelsel te vermeerder en te verfyn. Dink maar net watter verstommende orde daar vandag in rekenaars ingebou is. Hierdie teoloë verwys na die opdrag wat God reeds voor die sondeval aan die mens 
gegee het, om die tuin te onderwerp en daaroor te heers, en om dit te bewerk en te bewaak (Gen 1:28; 2:15). Die opdrag kan onder andere dui op die ontwikkeling van tegnologie.

Johan Heyns het so 'n optimistiese siening van tegnologie teologies uitgewerk. Hy het gesê dat die mens in die tegnologie (en ander aktiwiteite, soos kuns) nie net skepsel is nie, maar mede-skepper met God. In die tegnologie bevestig die mens sy roeping om te heers oor die skepping van God en styg die mens bo die natuur uit. In die tegnologie word die natuur die toekoms ingedra, as verwerkte, verfynde natuur. Die toekomstige gestalte van die koninkryk van God is 'n stad, die ewige stad van God. Die stad van God lê êrens in die verlengde van die stede waarin ons woon. Ons stede word deur middel van tegnologie gebou. Deur die tegnologie kan iets van die ewige Godstad nou reeds manifesteer. Heyns sê beskawing is kultuur wat aan sy Godbepaalde roeping, om te heers oor die natuur, beantwoord. 'n Primitiewe kultuur, aan die ander kant, se omgang met die natuur is nog gebrekkig (Heyns 1972:55; 1974:112, $114,118,119-120,123 ; 1977: 16,17)$.

Heyns plaas 'n teologiese stempel op die vooruitgangsgeloof van die modernisme. Hy bied 'n buitengewoon optimistiese teologie van die tegnologie: deur die tegnologie kan die mens saam met God skeppend en ordenend aan die wêreld werk. Heyns gee egter min aandag aan die komplikasie daaraan verbonde, naamlik dat ons pogings om orde te skep, volgens die ervaring en volgens die tweede wet van die termodinamika, die totale wanorde kan vermeerder. Heyns glo dat die mens in die tegnologie bo die natuur uitstyg. Dit beteken dat die mens in die tegnologie selfs bo die tweede wet van die termodinamika kan uitstyg. Ons kan egter vra: is die voortgaande skeppende krag van God so sterk in die tegnologie werksaam as wat Heyns dit wil? Hoe herken ons God se werkende teenwoordigheid in die tegnologie?

Die postmodernisme is meestal skepties oor die vooruitgangsgeloof van die modernisme, maar in sekere postmoderne chaosteorieë word die tweede wet van die termodinamika tog op so 'n wyse bespreek, dat daaraan 'n optimistiese betekenis gegee word. Dit word gedoen deur die orde-vormende prosesse wat in chaos waargeneem word, aan 'n natuurwet toe te skryf en nie aan God of die toeval nie.

In die chaosteorie het daar onlangs die siening ontwikkel dat orde en kompleksiteit op 'n natuurlike wyse ontwikkel op alle vlakke in die heelal: “... evolution is the result of a general pressure toward increasing levels of tightly integrated ordered energy flows - 'ordered complexity'.... Evolution is a general 
process that proceeds inexorably and opportunistically to higher and higher levels of ordered complexity." Die tweede wet van die termodinamika, wat vir 'n lang tyd as 'n "antiorder principle" verstaan is, sou volgens hierdie benadering uitgebrei moet word deur 'n ordeskeppende faktor as fisiese wet daarby te voeg (Goerner 1995:18, 19). In hierdie siening word die Christelike belydenis van God as Skepper oorbodig gemaak en vervang deur te aanvaar (of te glo) dat daar 'n natuurlike dryfkrag na orde is. Dit is 'n optimistiese siening.

Die waarde van die pessimistiese en optimistiese sienings van die tegnologie (en die geskiedenis) vir ons lewe in Afrika word vervolgens getoets deur, eerstens, 'n evaluasie van die effektiwiteit van 'n bestaande projek van ESKOM en tweedens, 'n teologiese beoordeling van die gegewens.

\section{DIE PRAKTIESE RESULTATE VAN DIE NEDCOR-OLD MUTUAL SCENARIOS}

ESKOM sal sy visie normaalweg nie, saam met Heyns, beskryf in terme van die Bybelse taal of die Christelike belydenis nie, maar in terme van modernisering, ontwikkeling en vooruitgang. ESKOM se visie vergestalt die geloof in vooruitgang soos wat dit in die moderne Westerse kultuur voorkom, wat toegepas word op die Afrika van ons tyd. Hierdie visie vir Afrika het oor jare ontwikkel. ESKOM het homself tien jaar gelede reeds as agent van modernisering gesien. ESKOM het heel tereg besef dat elektrisiteit nie neutraal is nie, maar 'n bepaalde kultuur, en met name modernisering, bevorder.

In 1991 is die visie reeds wyer as Suid-Afrika gestel: dat ESKOM die draer kan word van ekonomiese ontwikkeling wat lande in Afrika suid van die Sahara uit hulle ekonomiese moeras kan red (Liebenberg 1991:17, 19). In 2001, tien jaar later, word die visie uitgebrei tot binne in die Sahara self.

Vir hierdie grootse visie kan die elektrifiseringsprojek of Electrification Drive wat in 1991 geloods is, as toetssaak gebruik word.

In 1991 het ESKOM die Electrification Drive geloods, met die doel om 3 miljoen arm huishoudings van elektrisiteit te voorsien in vyf jaar. Die doel was modernisering. A J Morgan, wat kort daarna die besturende direkteur van ESKOM geword het, het dit in 1992 as volg verduidelik: die elektrifisering van gemeenskappe sal lei tot die ontwikkeling van tegnologie, ekonomiese en sosiale ontwikkeling, moderne kommunikasie, verbetering van die onderwys, werkskepping, ensovoorts. Morgan (1992:2, 6, 7) som die rol van elektrisiteit as volg op: "It is a key to technological development and modernisation" 
Elektrifisering, word verwag, sal voordelige resultate hê op ander terreine as net die energie-terrein. Deur orde op een terrein te vermeerder, word orde terselfdertyd op ander terreine vermeerder. Dit is die optimistiese teenoorgestelde van die tweede wet van die termodinamika, wat sê dat die bevordering van orde op een terrein tot gevolg sal hê dat chaos op ander terreine sal toeneem.

Die Electrification Drive was deel van 'n groter plan, wat uiteengesit is in die Nedcor-Old Mutual Scenarios (Tucker en Scott, 1992). Die noue verband tussen die Electrification Drive en die Scenarios blyk onder andere daaruit dat mnr John Maree, wat voorsitter van ESKOM se direksie was in daardie tyd, ook medevoorsitter van Nedcor was en dat hy die voorwoord tot die Scenarios geskryf het.

Die beoordeling van die effektiwiteit van die elektrifiseringsprojek word vervolgens gedoen as deel van die beoordeling van die Nedcor-Old Mutual Scenarios. Die Scenarios het modernisasie as doelwit gestel, onder andere omdat dit gesien is as 'n metode om sosio-politieke stabiliteit te bevorder. Daar is 'n studie gemaak van ander lande wat, soos Suid-Afrika, omvattende sosiopolitieke transformasie deurgegaan het. Die gevolgtrekking was dat sodanige transformasie nie kan slaag as die meeste mense nie sigbare en voelbare verbeterings in hulle daaglikse omstandighede en lewenskwaliteit ervaar nie. Die gewensde verbeterings kan deur moderne ekonomiese ontwikkeling teweeggebring word.

Daar is ook meer pessimistiese sienings van moderne ekonomiese ontwikkeling. Die sosioloog Peter L Berger (1974:122) beweer dat modernisering neig om mense se verwagtings te verhoog, wat kan lei tot ontevredenheid en mobilisering van verset. Hy praat van 'n wydverspreide verband tussen modernisering en 'n rewolusionêre bewussyn.

Die Scenarios stel, volgens die optimistiese siening, ' $n$ "change of gears" of "kickstart"-strategie voor, in teenstelling met 'n geleidelike of evolusionêre groeiproses. So 'n ratverwisseling moet vinnige en sigbare resultate lewer, maar tog volhoubaar wees. Die Scenarios stel massiewe beleggings in die swart gemeenskap voor, gerig op produksie eerder as verbruik. Die volgende voorstelle word voorgelê:

- Behuising: Verskaffing van 400000 gedienste erwe en 200000 lae-koste eenhede per jaar teen 1995 (Tucker en Scott 1992:135 en 162). 
- $\quad$ Elektrifisering: Dit word gesien as 'n "very high priority for creating a producer environment for all household blacks." Om so 'n produksieomgewing te vestig word voorgestel dat 1 miljoen huise per jaar vanaf 1994 van elektrisiteit voorsien word (Tucker en Scott 1992:139 en 162).

- $\quad$ Opleiding: Gelyke, verpligte en gratis primêre skoolopleiding, asook voldoende post-primêre onderrig om die nodige vaardighede vir ekonomiese groei daar te stel (Tucker en Scott 1992:141).

- $\quad$ Werkgeleenthede: Moet gevestig word deur middel van produksiegebaseerde uitvoere. Miljoene jongmense wat die skool verlaat en nie werk kry nie, word vervreem van die sosiale bestel ("alienated from the system"). Produksie-gebaseerde uitvoere bied 'n geleentheid om hulle deel te laat word van die stelsel (Tucker en Scott 1992:129, 145).

- Gesondheidsorg: MIVIVIGS word in die Scenarios erken as 'n groot bedreiging. Die sukses van die voorgestelde maatreëls word afhanklik gestel daarvan dat Suid-Afrika MIVIVIGS onder beheer kry en homself duidelik onderskei ("clearly distinguish") van Afrika as siek kontinent ("plague continent") (Tucker en Scott 1992:153).

Hierdie Scenarios bied 'n goeie voorbeeld van die denkwyses van die Westerse modernisme en die Afrikaanse Verligte beweging. Die Scenarios stem ooreen met die verligte benadering wat Willem de Klerk $(1991: 130,145,175)$ in die tyd beskryf het. Gesamentlikheid, sê De Klerk, was die "moederbegrip" van die verligtes; die gesamentlikheid is gebaseer op kennis, oortuiging en rede, wat die natuurlike wette van die menslike siel is; die rede vind gestalte in ontwikkeling van die ekonomie en politiek volgens ' $n$ "Westerse oriëntasie." Bekende verligtes soos Willem de Klerk en Willie Esterhuyse was deel van die groep wat die Scenarios opgestel het - die oorgrote meerderheid van hulle wit mans uit die akademie en die besigheidswêreld. Die denkwyse verwag dat redelike denke en beleid op Westerse patroon gepaste redelike respons van die bevolking sal ontlok - gepas volgens die norme van die moderne Weste, wat meer of minder bewustelik as norm geld waarheen alle ander kulture op pad is, of behoort te wees.

As die opstellers van die Nedcor-Old Mutual Scenarios reg was met hulle aanname dat die sukses van die politieke transformasie afhanklik is van die 
sukses van bogenoemde voorstelle, is ons land in groot moeilikheid, soos blyk uit die volgende gegewens:

- $\quad$ Behuising: Daar word tans sowat 170000 lae-koste huise per jaar gebou met regeringsubsidie. Of die huisies mense se lewenskwaliteit werklik verbeter, is ' $n$ vraag. Die huisies is baie klein en swak ontwerp.

- $\quad$ Opleiding: Volgens die Department van Onderwys het die aantal matrikulante van 287343 in 1994 gedaal na 249831 in 1999, en die met universiteitstoelating van 88497 na 63725 in dieselfde tyd (Mattison 2000:1).

- Werksgeleenthede: Sedert 1990 verloor die formele ekonomie jaarliks sowat 100000 werkgeleenthede (De Lange 2000:2).

- $\quad$ MIVIVIGS: Suid-Afrika het die "plague continent", soos Afrika in 1992 deur die Scenarios beskryf is, intussen ingehaal en verbygesteek. Ons het van die hoogste vlakke van hierdie siekte ter wêreld.

'n Mens kan tot die konklusie kom dat die Nedcor-Old Mutual Scenarios se optimistiese verwagtings nie gerealiseer het nie. Daar mag baie redes voor wees, maar dit is geen uitsondering nie. Dieselfde patroon is oor en oor herhaal dwarsoor Afrika, sedert die president van Amerika in 1949 die massiewe internasionale ontwikkelingsbedryf geloods het. Daar is 'n breë (pessimistiese) konsensus in die wêreldwye media vandag dat die massiewe beleggings in Afrika weinig goed opgelewer het, en dikwels meer skade gedoen het as goed (vgl Van Niekerk 2002:171). Finansiële beleggings is drasties aan die verminder. Beide die Wêreldbank en die Internasionale Monitêre Fonds het in September 1999 erken dat hulle 'n analitiese deurbraak sal moet maak as hulle impak wil maak op die lewenskwaliteit van die meerderheid mense in Suid-Afrika (Ngubane 2000:2).

\section{DIE RESULTATE VAN ESKOM SE ELECTRIFICATION DRIVE}

Die resultate van een voorstel in die Scenarios, elektrifisering, is nie hierbo genoem nie. Is dit nie tog 'n suksesverhaal nie?

Tussen 1994 en Maart 2001 is 1167435 arm huishoudings van elektrisiteit voorsien (ESKOM statistiek). Miljoene kinders kan saans by elektriese 
lig studeer. Mense kan klein besighede begin. Gesinne kan televisie kyk. Rekenaars kan gebruik word, en die internet daarmee saam. Afstandsonderrig word moontlik. Strate is verlig. Dit is tog positiewe gevolge!? En dan is dit tog goed dat die voordele uitgebrei word na Afrika, en dat ons selfs vergesigte kan sien van vrugbare landerye in die Saharawoestyn!

Of verloop dinge nie so reglynig nie? Die praktiese resultate van die elektrifiseringsprogram word nou oorweeg aan die hand van 'n aantal kriteria, naamlik:

- Volhoubaarheid;

- $\quad$ Aanvaarbaarheid en/of aantreklikheid;

- Koste;

- $\quad$ Effektiwiteit om vrystelling van kweekhuisgasse te verminder;

- $\quad$ Effektiwiteit om gesondheid te verbeter, en

- Heilsaamheid.

\subsection{Volhoubaarheid}

Volhoubaarheid dui op die vermoë van 'n sekere oplossing om voortdurend te bly funksioneer in die sosiale, ekonomiese en ekologiese kontekste.

- $\quad$ Sosiale volhoubaarheid dui op die bereidheid en vermoë van die verbruikersgemeenskap om die oplossing in stand te hou. Dit is afhanklik daarvan hoe goed die bepaalde oplossing inpas by die sosiale patrone van die verbruikersgemeenskap en hoe aantreklik ("desirable") die oplossing vir verbruikers is (sien 6.2).

- $\quad$ Ekonomiese volhoubaarheid hang af van bekostigbaarheid (sien 6.3).

- Ekologiese volhoubaarheid hang af van die hernubaarheid van die natuurlike bron of bronne, asook hoeveel skade die oplossing die ekologie aandoen (sien 46.4).

\subsection{Aanvaarbaarheid en/of aantreklikheid}

Ondersoeke in die informele woongebiede en "townships" dui daarop dat elektrisiteit baie hoog in aanvraag is vir ligte, radio's en televisie, maar nie soveel vir koskook en ruimteverhitting nie. Dit blyk dat elektrisiteit nie alle sosiale behoeftes bevredig nie. 
In Duncan Village, Oos-London, was daar in die tien jaar voor 1996, 359 brande in huishoudings, waarin 2300 huise vernietig is. Dit is gemiddeld een brand elke tien dae, of een huis wat per dag vernietig word. Die brande word meestal deur paraffien veroorsaak. Mense sê: "Ons leef in vuur" ("We live in fire"). Paraffien is nie net gevaarlik nie, dit is boonop vuil en arbeidsintensief, wat baie tyd vat (Bank e a 1996).

Ten spyte van al die negatiewe gevolge, bevind 'n span navorsers dat $90 \%$ van die huishoudings in Duncan Village paraffien as energiebron verkies. Mense skakel voortdurend terug na paraffien nadat hulle elektrisiteit begin gebruik het.

Baie vrouens verkies paraffien, want dit beklemtoon dat hulle nodig is as tuisteskepper en moeder, juis omdat dit arbeidsintensief is. Paraffien bring boonop ' $n$ hele netwerk van sosiale verkeer, inter-afhanklikheid en onderlinge sorg tot stand, want vrouens leen paraffien oor en weer. En dit gee aan die vrou die geleentheid om die huishouding se geldsake te mistifiseer, en so 'n mate van mag te verkry teenoor die man.

Die mans verkies paraffien want, anders as elektrisiteit, bind paraffien die vrou aan die huis. Sy kan nie maar net 'n knoppie draai en dan by vriendinne gaan kuier nie. Die gevolg is dat elektrifisering nie die afbranding van huise tot 'n einde gebring het, soos verwag is nie.

\subsection{Bekostigbaarheid}

Die nie-betaal vir dienste, waarvan elektrisiteit 'n groot deel uitmaak, het baie plaaslike owerhede in finansiële krisisse laat beland (Van Tonder 2002:1) Volgens die redakteurs van ' $n$ RGN-verslag is tot 10 miljoen mense se water en/of elektrisiteit afgesny weens wanbetaling, sedert 1994 (McDonald en Pape 2002:22).

\subsection{Effektiwiteit om besoedeling te verminder}

Lugbesoedeling in huise wat steenkool gebruik, kan op verskeie maniere verminder word, waaronder:

- Beter verbranding van dieselfde hoeveelheid steenkool, wat skoner gasse vrylaat;

- $\quad$ Vermindering van die hoeveelheid steenkool wat gebruik word, en 
- Vervanging van steenkool met 'n brandstof of energiedraer wat minder besoedeling vrystel.

Daar moet onderskei word tussen twee soorte besoedeling: die vrylating van gasse wat sleg is vir ' $n$ mens se gesondheid, en die vrylating van kweekhuisgasse wat nie noodwendig ' $n$ direkte nadelige gevolg het vir menslike gesondheid nie. Sommige metodes om besoedeling te verminder is meer effektief ten opsigte van die een soort besoedeling, ander metodes weer ten opsigte van die ander soort.

As steenkool, hout, gas of ander koolwaterstofverbindings verbrand word, word 'n verskeidenheid gasse vrygestel. Sommige gasse, soos koolsuurgas $\left(\mathrm{CO}_{2}\right)$ is nie nadelig vir die mens se gesondheid nie, maar word wel as ' $\mathrm{n}$ kweekhuisgas beskou, wat nadelig is vir die globale ekologie. Die rede is dat, as die konsentrasie kweekhuisgasse in die atmosfeer verhoog, dit tot gevolg het dat minder hitte-energie van die aarde na die ruimte uitgestraal word en dat die aarde dan al hoe warmer word. Dit kan allerhande rampe en katastrofes veroorsaak, en is 'n rede tot groot kommer in die wêreld.

Ander gasse het'n nadelige impak op mense se gesondheid vanweë allerhande chemikalië wat vrygestel word as steenkool of hout nie volledig verbrand nie. As steenkool egter in goeie omstandighede volledig verbrand, word die meeste van bogenoemde chemikalië in die proses verbrand, en word hoofsaaklik koolsuurgas ('n kweekhuisgas) en water vrygestel.

In die berekening van die effektiwiteit van elektrisiteit om lugbesoedeling te verminder moet daar gevolglik onderskei word tussen die verminderde vrystelling van ongesonde gasse, en die verminderde vrystelling van kweekhuisgasse.

Die huishoudelike gebruik van steenkool behels sowat $3 \%$ van die totale steenkoolgebruik in die land, en dieselfde persentasie (3\%) van die kweekhuisgasse wat vrygestel word weens steenkoolgebruik. Daardie 3\% van die steenkool veroorsaak egter sowat $36 \%$ van die totale lugbesoedeling wat skadelik is vir gesondheid in gemeenskappe wat steenkool gebruik. In die winter styg dit tot 65\% (Annegern 1998:vi \& vii, 47).

Altwee vorme van besoedeling sal verminder indien steenkool vervang word met 'n brandstof wat meer waterstof $\left(\mathrm{H}_{2}\right)$ atome bevat vir elke koolstof (C) atoom in die brandstof. Sodoende word daar by verbranding meer water $\left(\mathrm{H}_{2} \mathrm{O}\right)$ vrygestel, en minder koolsuurgas $\left(\mathrm{CO}_{2}\right)$, vir 'n gegewe hoeveelheid hitte-energie. Metanol en aardgas is voorbeelde van sulke skoner brandstowwe. 
Beter verbranding van 'n gegewe hoeveelheid steenkool sal wel 'n effek hê op die vrystelling van rook wat nadelig is vir die gesondheid, maar dit sal nie die vrystelling van die hoeveelheid koolsuurgas, wat een van die kweekhuisgasse is, verminder nie. Om 'n effek te hê op die vrystelling van kweekhuisgasse, moet die hoeveelheid steenkool wat verbrand word, verminder word.

Die effektiwiteit van elektrisiteit om hierdie twee vorme van besoedeling te verminder, word vervolgens afsonderlik bespreek.

\subsubsection{Effektiwiteit om gesondheid te verbeter}

Die Departement Minerale en Energie (DME) het onlangs bereken dat die huishoudelike gebruik van steenkool die regering sowat R800 miljoen per jaar kos aan gesondheidsorg vir mense wat lugweginfeksies opdoen weens hoë vlakke van lugbesoedeling. Dit sluit nie die koste vir die gesinne self en die verliese aan produktiwiteit in nie (DME Interne verslag, 2002).

Die Elektrifiseringsprojek het die verwagting gewek dat elektrisiteit steenkool as energiedraer sou vervang, en dat dit sou lei tot "the elimination of township pollution ....." Die verwagting word egter deur 'n navorser, Penny Hoets (1995:9) bestempel as 'n "mite." In Evaton het 81\% van die mense wat elektrisiteit in hulle huise gehad het, gesê dat hulle "definitief" nie bereid was om hulle steenkoolstowe prys te gee ter wille van skoon lug nie. Soortgelyke resultate is gevind in Qalabotjha, naby Villiers, waar $86,1 \%$ gesê het hulle wil hulle steenkoolstowe behou (Social Surveys 1997, vraag 27).

In 'n opname wat NOVA in die jaar 2000 onder 1023 laekostehuishoudings gemaak het, is bevind dat elektrifisering nie veel effek gehad het op die hoeveelheid steenkool wat gebruik is nie, en dit selfs verhoog het (Van Niekerk en Swanepoel 2002, Appendix B, p13).

Die rede(s) hiervoor is tans nog onbekend. Dit lyk nie asof inkomste 'n rol speel nie. Wat ons wel weet, is dat baie mense elektrisiteit gebruik vir ligte, televisie en radio, maar nie soseer om kos te kook of die huis te verwarm nie. As daar dan elektrisiteit is, bly mense saans later wakker om televisie te kyk of te leer, en dan mag hulle in die winter meer steenkool op die vuur gooi om die huis te verwarm. As dit gebeur, is die gevolg van elektrifisering om besoedeling te vermeerder en nie te verminder nie, wat 'n nonlinieêre oorsaak-en-gevolgproses is. 


\subsubsection{Effektiwiteit om die vrystelling van kweekhuisgasse te verminder}

Heelwat energie gaan verlore in die omskakeling van hitte-energie na elektrisiteit, wat dan in 'n huis gebruik word om weer hitte te verskaf om kos te kook of water te verwarm. Die gevolg is dat elektrisiteitsgebruik nie noodwendig daartoe bydra om die vrystelling van kweekhuisgasse te verminder nie. Aan die anderkant is 'n elektriese stoof waarskynlik heelwat minder nadelig as 'n koolstoof, omdat dit afgesit kan word as die energie nie meer nodig is nie.

\subsection{Heilsaamheid}

Die term "heil" verwys na die totale wel-wees van mense. Dit hou verband met woorde soos heel en heilig (Engels: whole, holy). Verskeie Bybelse begrippe dui eweneens op so 'n toestand van totale wel-wees, reg-wees, in-orde-wees: vrede (sjaloom, eirene), geregtigheid, heiligheid, koninkryk van God, salig, volmaak. Verlossing en seën is dade van God waardeur so 'n volkome toestand aan die mens toegeken word.

Die term "heilsaamheid" dui op die gevolge wat 'n sekere menslike aksie het vir die totale of hele lewenskwaliteit van almal wat deur daardie aksie beïnvloed word of sou kon word, insluitende komende geslagte. Dit beteken dat die oplossing van een probleem nie probleme elders veroorsaak of vererger nie.

In die geval van elektrifisering sal ondersoek moet word hoe die totale lewenstyl van mense beïnvloed word. Het elektrifisering verhoudings binne die gesin verbeter of verswak? Hoeveel shebeens en hoeveel produktiewe klein besighede het daar ontstaan? Hoe het mense se waardes verander?

\subsection{Konklusie}

Die optimisme wat die Old Mutual-Nedcor Scenarios en die Electrification Drive sowat 'n dekade gelede gekenmerk het, moet dalk vandag deur groter realisme vervang word. Modernisasie en ontwikkeling is die afgelope eeu as oplossing vir Afrika aangebied en het, benewens groot verbeterings in baie mense se lewenskwaliteit, groot ontwrigting van sosiale en ekologiese stelsels en patrone meegebring. As die optimistiese, liniere denke van die modernisme nie meer voldoende is nie, wat is dan die alternatief? Die volgende benaderings word ter oorweging voorgelê en kortliks bespreek: 
- $\quad$ Ontwikkeling, waar die Weste sy oplossing aan Afrika voorskryf, moet vervang word deur 'n proses waar oplossings saam ontwerp word, en

- $\quad$ Die moderne optimisme moet vervang word deur die Christelike hoop.

\section{SAAM ONTWERP TEENOOR EENSYDIG VOORSKRYF}

Die ontwikkelingsbenadering kom voort uit ' $n$ bepaalde probleemformulering, naamlik dat Afrika, gemeet aan die Weste, onderontwikkeld, agtergeblewe, verontreg, ensovoorts is. Die probleemformulering lei tot 'n benadering waarin oplossings wat in die Weste gewerk het, aan Afrika voorskryf word, soos ekonomiese ontwikkeling, politieke bevryding en demokrasie. Hierdie benadering het egter nie daarin geslaag om 'n sinvolle verhouding en volhoubare interaksie tussen Westerse tegnologie en die Afrika-kulture, of tussen hulle albei en die ekologie daar te stel nie.

'n Alternatiewe benadering kan ontwikkel word uit die stelselteorië en chaosteorië (waar die tweede wet van die termodinamika meermale ter sprake kom). Volgens hierdie benadering sou dit veel meer sinvol wees om die moderne Weste met sy tegnologie, en tradisionele Afrika met sy diepgewortelde patrone en waardes, en die ongelooflike natuur van Afrika, op 'n volhoubare en lewegewende wyse in wisselwerking te bring. Al drie: die Westerse kultuur, die Afrika kultuur en die natuur, is groot en komplekse stelsels. Hulle is gedurig in interaksie. Daar vind gedurig nuwe kombinasies tussen hulle plaas, nuwe botsings, nuwe breuke.

Ons kan die probleem formuleer as: die disfunksionele interaksie tussen komplekse stelsels. Hierdie probleem-formulering lei logies tot die volgende formulering van die oplossing waarna gesoek moet word: die konstruksie of ontwerp van funksionele interaksies of kombinasies van of tussen die gegewe stelsels. Die wisselwerking sal die gepaste aanpassing, ontwikkeling, transformasie, vernuwing, bekering en/of heiligmaking van almal vereis. Wat gepas is, sal algaande ontdek en onderhandel moet word.

Omdat hierdie stelsels ons hele natuurlike werklikheid omvat - daar is ekologiese siklusse, waardestelsels, sosiale patrone, ekonomiese konstellasies, regsordes, politieke strukture, kulturele denkwyses, wêreldbeskouings, ens - sal die tegnologie sy plek in hierdie totale kompleks van bewegende verbindings moet vind.

Die tegnologie is nie in beheer nie. Hy kan sy orde nie op Afrika afdwing nie. Tegnoloë sal moet leer om in te speel op die groter patrone. Terwyl hulle die 
werklikheid vorm en verander, sal hulle self in die proses moet verander. Eerder as om die werklikheid na hulle eie wil te probeer orden soos die modernisme dit wil, sal hulle met nuwe ontwerpe vorendag moet probeer kom wat die orde en harmonie tussen stelsels so veel moontlik vermeerder, of dan, die wanorde so min moontlik vermeerder.

Die tegnologie kan in die komende eeu wél beter vaar, as ons leer hoe om ons kennis op 'n lewegewende wyse te laat funksioneer in die gegewe, dikwels chaotiese, prosesse en patrone van die Afrika van die een-en-twintigste eeu.

Die standpunt dat tegnologie wél die lewe op 'n beperkte skaal kan beter maak, wys beide die oormoed en die totale moedeloosheid af. Dit is 'n standpunt wat nie net realisties lyk nie, maar ook in ooreenstemming met dit wat ons in die Bybel lees in verband met die Christelike hoop.

\section{DIE NIETIGWORDING VAN DIE BESTAAN IN DIE BYBEL, EN DIE CHRISTELIKE HOOP}

Die Christelike hoop is baie realisties oor die verbete boosheid van ons wêreld, wat ons van oormoed weerhou. En tog verval die Christelike hoop nie in 'n tragiese visie nie. Die Christelike evangelie bied hier nuwe moontlikhede vir beide optimisme en Afro-pessimisme, wat keersye van dieselfde proses is - want optimisme lei een of ander tyd tot pessimisme.

In Romeine 8:19, 20 en 21 word in die 1953-vertaling die volgende gesê: "Want die skepping wag met reikhalsende verlange op die openbaarmaking van die kinders van God. Want die skepping is aan die nietigheid (mataios) onderworpe in die hoop dat die skepping self vrygemaak sal word van die slawerny van die verganklikheid tot die vryheid van die heerlikheid van die kinders van God." Dit is 'n direkte vertaling van die oorspronklike woorde. Wat sou dit beteken?

Die vertalers van Die Boodskap, Van der Watt en Joubert (1997) vertaal dit soos volg:

... tot nou toe kry die skepping baie swaar. Hier gaan alles dood. Alles vergaan. Natuurlik is dit nie die skepping se skuld dat dit so moet ly nie. Nee, dit is Adam se skuld. Sy sonde het gemaak dat die skepping nou so swaarkry en vernietiging moet beleef. Tog is daar hoop. Die skepping weet dat God dit eendag sal bevry van hierdie verskriklike lyding. Op daardie dag wanneer God al sy kinders eens en vir altyd kom verlos, sal die skepping ook vrygemaak word. Dan sal die skepping God se heerlikheid op die regte manier weerkaats. Vir altyd. 
Die vertaling vat 'n aantal kommentare netjies saam. Tog is die betekenis moeilik vas te pen en moet ' $n$ mens binne die groter raamwerk van die Bybel daaroor besin. Die gedeelte stimuleer nadenke.

As God die skepping eendag sal verlos, watter rol het ons en ons tegnologie dan vandag? In Romeine 8 word die "nog nie" van die koninkryk van God sterk beklemtoon. Daar is in die Nuwe Testament, naas die "nog nie" egter ook sprake van 'n "reeds." Die heerlikheid van God se verlossing is reeds aanwesig omdat Jesus uit die dood opgewek is, maar dit is nog verborge en dit sal nog ten volle openbaar word. "Dit kan egter eers gebeur wanneer die kroon van die skepping, die mens, deur wie se sonde die skepping in die ban van die nietigheid gekom het, in heerlikheid herstel word" (Jonker 1967). Dit sal God doen, nie die mens nie. Die skepping word bo die chaos bewaar van buite die skepping, deur God. As God sy hand wegneem, gaan alles tot niet (Barth 1947:54-56). En tog sluit die werk van God ons menslike pogings nie uit nie.

Die opstanding en hemelvaart van Jesus beteken, naas die "nog nie", dat daar nou reeds positiewe moontlikhede vir hierdie wêreld is, wat nou reeds vir die hele skepping geld. Die Bybel stel nie die toename van die wanorde as enigste moontlikheid voor nie. Teoloë praat eerder van twee gelyktydige moontlikhede in die Bybel: ' $n$ verhewiging van chaos en ellende, tesame met groei en vooruitgang.

Die teenstrydige reaksies begin reeds in die tyd van Jesus: Hy kom na sy eiendom toe om lig en lewe te bring, maar hy word verwerp en gekruisig. Tog is daar diegene wat hom wel aanneem. Al word Hy verwerp, en al neem wanorde toe, begin die koninkryk van God reeds uitbrei oor die aarde.

Die teenstrydige reaksies op die boodskap van die evangelie in Jesus se tyd duur voort tot vandag toe. Daar is koring en onkruid sáám op die land. Die Hollandse teoloog G C van Niftrik (kyk Berkhof 1973:537-538) stel dit mooi: beide die skaduwee van die kruis en die lig van die opstanding is oor die mensheid en oor ons hele geskiedenis afgeteken. Volgens Berkhof verhewig die ambivalensie met die tyd. In die boek Openbaring word daar twee groot moontlikhede vir die wêreld voorgehou. Die wêreldgeskiedenis kan uitloop op die vrederyk, of op die antichris. Die vrederyk dui op 'n wêreld wat volgens die orde van God leef; die antichris dui op 'n wêreld wat die orde van God verwerp: "Onze geschiedenis loopt uit op en loopt vast in twee machten die elkaar oproepen, begrenzen en niet overwinnen kunnen." Eers met die tweede koms van Jesus word die geskiedenis beëindig en die stad van God volmaak gevestig. 
Indien ons niks van die tegnologie verwag nie, vergeet ons dat die Koninkryk reeds in die wêreld aan die kom is. Indien ons te veel verwag, vergeet ons dat dit nog nie volkome is nie. Die Christen se werk aan tegnologie, soos al die werk van die kerk, bestáán in die spanning tussen die "reeds" en die "nog nie." Dit is ons Christelike hoop. Dit maak dit vir ons moontlik om positief betrokke te wees (teenoor die pessimisme), sonder om naïef en voortvarend te wees (teenoor optimisme).

\section{ESKOM SE VISIE EN SINVOLLE BESTAAN}

In die lig van die bespreking tot dusver kan ons probeer om 'n paar opmerkings te maak oor die verband tussen ESKOM se visie en die soeke na 'n sinvolle bestaan. Die twee voorwaardes, of die visie ooreenstem met dit wat ons glo, en of die visie prakties haalbaar is, sal deurgaans in gedagte gehou word.

- $\quad$ ESKOM se visie kan gesien word, deur die wat die Christelike geloof bely, as 'n aktiewe, positiewe aansluiting by en respons op die Christelike belydenis dat God die Skepper is wat orde in sy skepping handhaaf en selfs vermeerder, en aan die mens opdrag gee om dieselfde te doen. Die mens se arbeid in die tegnologie reik uit na dit wat ons verwag God aan die einde volkome sal doen.

- $\quad$ ESKOM se visie stem verder ooreen met die Christelike deernis en barmhartigheid, in soverre as wat ESKOM voedsel wil produseer in 'n kontinent waarin daar groot hongersnood is. Die visie om voedsel te produseer staan, byvoorbeeld, in sterk kontras met die groot toename in die spandering aan wapens wat ons kontinent steeds kenmerk.

- $\quad$ ESKOM se visie kan egter goedskiks van die Christelike waardes wegbeweeg en aansluit by die moderne idee van vooruitgang deur die mens se beheer oor die natuur. Hierdie gedagte neig om God uit te sluit en die mens se wil tot mag vrye teuels te gee. Dit sou daartoe kon lei dat die vrugbare landerye die magtiges bevoordeel en verryk maar vir die armes geen of weinig voordeel meebring nie, soos wat al herhaaldelik met ontwikkelingsprojekte gebeur het.

- $\quad$ Die verhouding tussen mens en tegnologie op die uitbeelding van ESKOM se visie is nie heeltemal duidelik nie. Die persoon, 'n meisie, wat die "foto" van die Sahara in die jaar 2056 vashou, het tradisionele Arabiese klere 
aan, maar is self grootliks onsigbaar. Die toekoms groei nie uit haar geskiedenis of kultuur nie. Die foto wys 'n landskap sonder mense. Die grootste beswaar van talle Afrika-skrywers teen Westerse tegnologie, dat dit 'n skeiding bring tussen mense en hulle tradisionele identiteit, asook tussen mens en natuur, bly onopgelos. Die tegnologie op hierdie uitbeelding is nie versoen met die mense, tradisies en kulture van Afrika nie.

- $\quad$ Die verhouding tussen tegnologie en die skepping of ekologie is ook onseker. Hoeveel wanorde of skade moet elders aangerig word, om die orde in hierdie stuk woestyn te probeer vermeerder? Hoe sal die krag opgewek word? Waar sal die water vandaan kom? Hoe wyd is die stelsels wat hier betrokke is, gedefinieer? Die tegnologie kan slegs sinvol aangewend word as dit orde vermeerder of, as dit nie kan nie, entropie so min moontlik vermeerder, in 'n stelsel of stelsels wat so wyd as moontlik gedefinieer word.

\section{GEVOLGTREKKING}

Moderne Westerse tegnologie kan nie 'n sinvolle rol in Afrika speel as dit ' $n$ blote onderdeel van die moderne of globale ekonomie bly nie. Maar as dit herdefineer kan word om sinvolle wisselwerkings, verhoudings en kombinasies tussen die moderne, globale Westerse wêreld, tradisionele Afrika, die ekologie, en ander relevante stelsels daar te probeer stel, kan daar kwalik 'n meer sinvolle roeping bedink word vir Christen-tegnoloë wat hulle daaglikse werk as diens aan die koninkryk van God wil uitleef.

\section{Literatuurverwysings}

Annegern, H J 1998. Direct source apportionment of particulate pollution within a township. Department of Minerals and Energy.

Bank, L \& Mlomo B. 1996. We live in fire and burn in it: Understanding fuel-use and fire in Duncan Village. Journal of Energy and Development in Southern Africa 8(4). Pretoria: Department of Minerals and Energy.

Bank, L, Mlomo, B \& Lujabe, P 1996. Social determinants of energy use in low income households in metropolitan areas (Eastern Cape). Journal of Energy and Development in Southern Africa. Pretoria: Department of Minerals and Energy.

Barth, K 1947. Dogmatics in outline, tr by G Thomson. London: SCM;

Bauernfeind, 1942. s v Mataios. ThWNT.

Berger, P L, Berger, B \& Kellner, H, 1973. The homeless mind. New York: Penguin. Berkhof, H 1973. Christelijk geloof. Nijkerk: Callenbach. 
Department of Minerals and Energy 2002: The social/health cost of burning coal in households. Unplished internal report .

De Klerk, F W 1991. F W De Klerk: Die man se tyd. Kaapstad: Tafelberg.

De Lange, J 2000. Suid-Afrika het verlede jaar 420000 werkloses bygekry. Sake-Beeld, 15 Feb, 2.

Frankl, V E 1980. Sê ja vir die lewe, verwerk deur F Deist. Kaapstad: Tafelberg.

Goerner, S 1995. Chaos, evolution, and deep ecology in Robertson, R \& Combs, A (eds), Chaos theory in psychology and the life sciences. New Jersey: Lawrence Erbaum Associates.

Heyns, J A 1974. Die mens. Bloemfontein: Pacum.

Heyns, J A 1972. Lewende Christendom. Kaapstad: Tafelberg.

Heyns, J A 1977. Die kerk. Pretoria: NG Kerkboekhandel.

Hoets, $P$ 1995. "My coalstove is my life, without it my life will be meaningless." Electrification of the townships: exploring some myths. Household energy for developing communities conference, 18-21 July 1995, the Southern African Institute of Energy.

Goudzwaard, B 1978. Kapitalisme en vooruitgang. Assen: Van Gorcum.

Jammer, M 1973. Entropy in Wiener, Philip P (ed), Dictionary of the history of idea, II, 112-120.

Jonker, W 1967. Die brief aan die Romeine. Kaapstad: NG Kerk-Uitgewers.

Liebenberg, J S 1991. Eskom, the genie that can uncork Southern Africa's riches. American Review 11(4)

Mattison, John 2000. Grim truth behind the matric spiral. Sunday Independent, 23 Jan 2001, 1.

McDonald, D \& Pape, J 2002. Cost recovery is not sustainable. Mail \& Guardian, 30 Aug-5 Sep, 22.

Morgan, A J 1992. The importance of the electrification drive. Paper read at the Electricity for Development Research Forum, 8 May 1992, Eskom, 2, 6, 7.

Ngubane, B 2000. Opening address by the minister of arts, culture, science and technology, Dr Ben Ngubane, Colloquium on the African Renaissance, Johannesburg.

Social Surveys \& Penny Hoets 1997. Low smoke fuel macro experiment study in Qalabotjha-Villiers. Benchmark Survey, Part I. Pretoria: Department of Mineral and Energy Affairs.

Tucker, B \& Scott, B R 1992. South Africa. Prospects for successful transition: NedcorOld Mutual Scenarios. Kaapstad: Juta.

Van der Watt, J \& Joubert, S 1997. Die Boodskap: Die Nuwe Testament in hedendaagse Afrikaans. Vereeniging: CUM.

Van Niekerk, A 2002. Apartheid en armoede: wat moet die NG Kerk bely? NGTT 43 (1\&2), 164-176.

Van Niekerk, A \& Swanepoel, P 2002. Clean household energy strategy. Pretoria: Departement Minerale en Energie.

Van Tonder, J 2002. Munisipaliteite in ernstige geldknyp. Sake-Rapport, 16 Junie, bl 1. 